\title{
THE ORAVA DAM RESERVOIR - AN IMPORTANT SITE OF AQUATIC MOLLUSCS IN NORTH-WESTERN SLOVAKIA
}

\author{
LUBOŠ BERAN
}

\begin{abstract}
Nature Conservation Agency of the Czech Republic, Regional Office Kokořínsko - Máchův kraj Protected Landscape Area Administration, Česká 149, CZ-276 01, Mělník, Czech Republic (e-mail: lubos.beran@nature.cz); (1) https://orcid.org/0000-0002-5851-6048
\end{abstract}

\begin{abstract}
Mollusc assemblages of the Orava reservoir, the biggest dam reservoir in Slovakia, were studied in 2020. The reservoir, built in 1941-1953, is situated in north-western Slovakia. Sixteen aquatic mollusc species (13 gastropods, 3 bivalves) were recorded. Valvata piscinalis (O. F. Müller), Radix auricularia (Linnaeus) and Gyraulus parvus (Say) were the most frequent; they were recorded in more than ten sites each. Rich mollusc assemblages, composed mainly of gastropods, were found in sites with rich littoral vegetation of macrophytes. The bivalve diversity and abundance were very small, especially compared to the other studied dam reservoirs. The current results were compared with the previous surveys. The occurrence of Radix lagotis (Schrank) is its first reliable record in Slovakia. Viviparus acerosus (Bourguignat), Aplexa hypnorum (Linnaeus), Anodonta cygnea (Linnaeus), non-native Potamopyrgus antipodarum (Gray) and Physa acuta (Draparnaud) were recorded in this area for the first time and their sites are outside their known range in Slovakia.
\end{abstract}

KEY WORDS: Mollusca; dam reservoir; mollusc assemblages; Orava; Radix lagotis

\section{INTRODUCTION}

Dams have been altering river ecosystems since humans started constructing them. The earliest dams were built 5,000 years ago (PETTS \& GURNELL 2005). Their primary function was to create perennial sources of water for irrigation. Water retention in dam reservoirs induces physical, chemical and biological changes, which also lead to changes in animal communities. Mollusc assemblages of selected dam reservoirs in the Czech Republic and Slovakia were studied in the last decades (e.g. DVOŘÁK \& BERAN 2004, BERAN \& DVOŘÁK 2006, BERAN 2007, 2020).

The Orava dam reservoir, with an area of $35.2 \mathrm{~km}^{2}$, is the biggest in Slovakia and has existed for almost 70 years. Its mollusc assemblages were studied in the past. In 1990 ŠTEFFEK (1991) analysed the sediments near the dam after emptying of the reservoir; his publication included also the results of several earlier visits in 1982, 1986 and 1989. He found 11 species and three species of pea mussels, found also in 1990 and mentioned later in ŠTEFFEK \& NAGEL (2004). LUČIVJANSKÁ (1991) studied the sediments in the reservoir in 1990 and found 12 species. The lack of data on the current composition of the mollusc assemblages, the fact that the previous surveys were mostly based on the contents of sediments and also the possibility to compare changes in the assemblages during more than 30 years were the main reasons for a more detailed survey of 2020. The results of this survey are presented here. 


\section{MATERIAL AND METHODS}

\section{STUDY AREA}

The Orava dam reservoir is situated in north-western Slovakia near the boundary with Poland at an altitude of $601 \mathrm{~m}$ a.s.l. and is the largest dam reservoir in Slovakia $\left(35.2 \mathrm{~km}^{2}\right)$. It was created by the construction of a dam between 1941 and 1953 on the former two sources of the Orava River. The average depth of the reservoir is 15 metres. Extensive wetlands are situated around it, especially along the northern shore of the reservoir.

\section{SAMPLING AND MATERIAL PROCESSING}

The survey was done in 2020. In total, 12 sites were sampled (Fig. 1, Appendix 1). The main sampling method was washing vegetation and sediments on a metal sieve (diameter $20 \mathrm{~cm}, 0.8 \mathrm{~mm}$ mesh) combined with collecting by hand from the surface of stones, wood and artificial materials (e.g. plastic bags and bottles) and with snorkelling in shallow parts (to the depth of ca. $3 \mathrm{~m}$ ). Collecting in each site lasted for about 45 minutes (excluding snorkelling). Based on the number of recorded specimens, the molluscs were divided into three categories of abundance (for explanation see Table 1).

Species were identified based on shell characters. When necessary, identification was based on the structure of copulatory organs. Specimens for dissection were killed in hot water and then fixed in $80 \%$ ethanol. Selected material of shells and alcohol-preserved specimens is deposited in the author's collection. Selected material of Radix lagotis (Schrank, 1803) was dissected and identified by KATRIN SCHNIEBS (Dresden, Germany). Otherwise classification used follows HORSÁK et al. (2020).

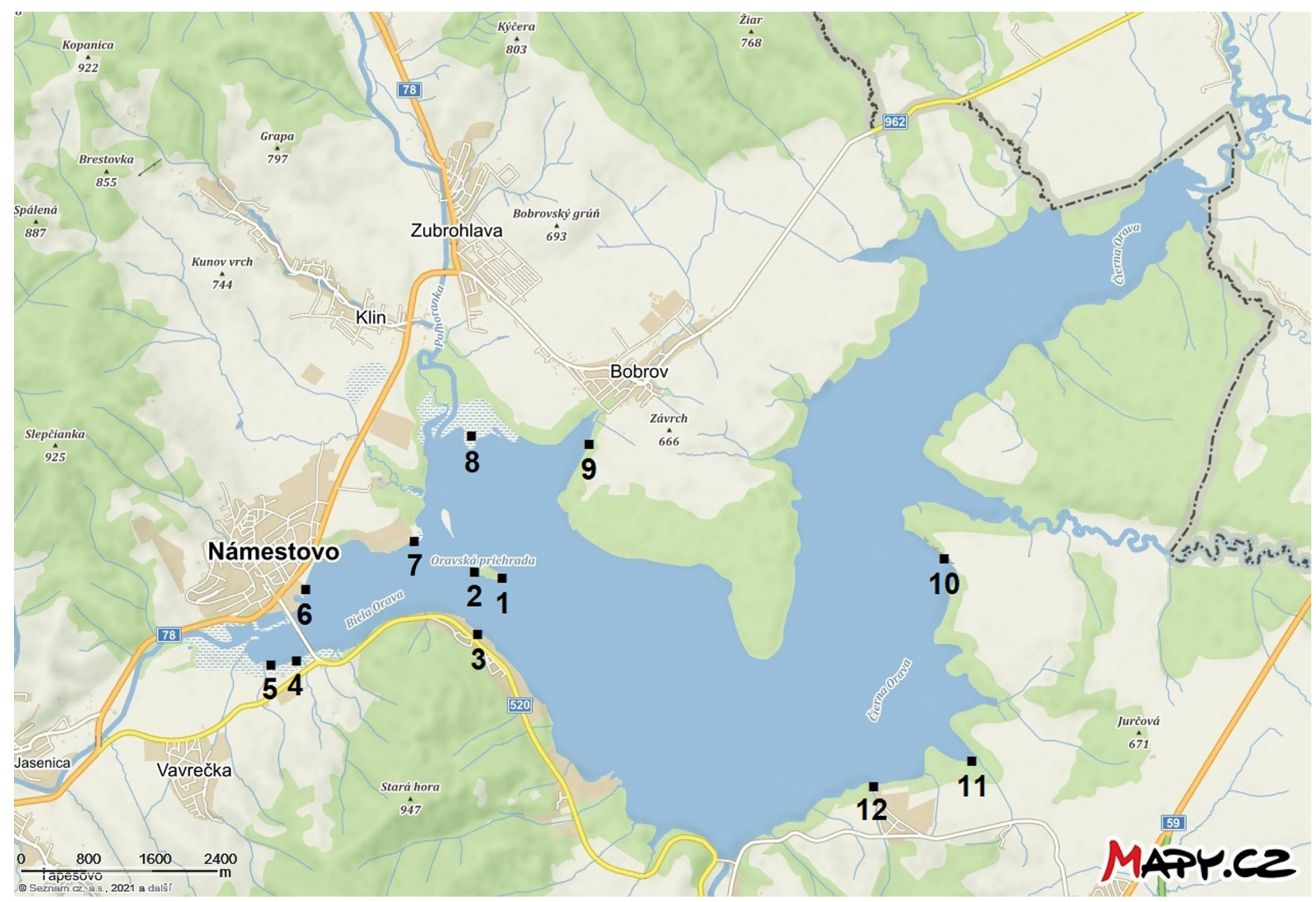

Fig. 1. Map of the Orava dam reservoir with the distribution of sampling sites. Background map: Mapy.cz @ Seznam.cz, a.s. 


\section{RESULTS}

In total, 16 species of aquatic molluscs (13 gastropods, 3 bivalves) were recorded at 12 sites of the Orava dam reservoir (Fig. 1). The assemblages docu- mented at particular sites consisted of 5-9 species. A list of molluscs found at particular sites and estimation of their abundance are shown in Table 1. Only

Table 1. List of aquatic molluscs recorded in the Orava dam reservoir: $\mathrm{x}$ - few specimens, $\mathrm{xx}$ - scattered occurrence, $\mathrm{xxx}-$ abundant occurrence

\begin{tabular}{|c|c|c|c|c|c|c|c|c|c|c|c|c|c|}
\hline Species/Site No. & 1 & 2 & 3 & 4 & 5 & 6 & 7 & 8 & 9 & 10 & 11 & 12 & $\Sigma$ \\
\hline Viviparus acerosus (Bourguignat, 1862) & & & & $\mathrm{xxx}$ & $\mathrm{xx}$ & & & & & & $\mathrm{x}$ & & 3 \\
\hline Potamopyrgus antipodarum (Gray, 1843) & $\mathrm{xx}$ & $\mathrm{x}$ & $\mathrm{xx}$ & & & & & $\mathrm{xx}$ & $\mathrm{x}$ & $\mathrm{x}$ & $\mathrm{x}$ & $\mathrm{x}$ & 8 \\
\hline Valvata piscinalis (O. F. Müller, 1774) & & $\mathrm{x}$ & $\mathrm{xx}$ & $\mathrm{xx}$ & $\mathrm{xx}$ & $\mathrm{x}$ & $\mathrm{xx}$ & $\mathrm{xx}$ & $\mathrm{xx}$ & $\mathrm{x}$ & $\mathrm{xx}$ & $\mathrm{xxx}$ & 11 \\
\hline Galba truncatula (O. F. Müller, 1774) & & & & & & $\mathrm{x}$ & & & & & & & 1 \\
\hline Stagnicola turricula (Held, 1836) & $\mathrm{xx}$ & $\mathrm{x}$ & $\mathrm{xx}$ & & $\mathrm{xx}$ & & $\mathrm{xxx}$ & $\mathrm{xx}$ & $\mathrm{xx}$ & & $\mathrm{x}$ & $\mathrm{x}$ & 9 \\
\hline Radix auricularia (Linnaeus, 1758) & $\mathrm{xx}$ & $\mathrm{xx}$ & $\mathrm{xx}$ & $\mathrm{xx}$ & $\mathrm{xx}$ & $\mathrm{xx}$ & $\mathrm{xx}$ & $\mathrm{xx}$ & $\mathrm{xx}$ & $\mathrm{xx}$ & $\mathrm{xx}$ & $\mathrm{xx}$ & 12 \\
\hline Radix lagotis (Schrank, 1803) & $\mathrm{x}$ & & $\mathrm{x}$ & & $\mathrm{xxx}$ & $\mathrm{xx}$ & & & $\mathrm{x}$ & & $\mathrm{xxx}$ & $\mathrm{x}$ & 7 \\
\hline Aplexa hypnorum (Linnaeus, 1758) & & & & & & & & $\mathrm{x}$ & & & & & 1 \\
\hline Physa acuta (Draparnaud, 1805) & $\mathrm{xx}$ & $\mathrm{x}$ & $\mathrm{xx}$ & $x x$ & $x x$ & $x x$ & & $\mathrm{xx}$ & $x x$ & $\mathrm{x}$ & & & 9 \\
\hline Gyraulus albus (O. F. Müller, 1774) & & & & & & $\mathrm{xx}$ & $\mathrm{xx}$ & $\mathrm{x}$ & & & $\mathrm{x}$ & & 4 \\
\hline Gyraulus crista (Linnaeus, 1758) & $\mathrm{x}$ & & $\mathrm{x}$ & & $\mathrm{x}$ & $\mathrm{x}$ & & $\mathrm{xx}$ & & & & $\mathrm{x}$ & 6 \\
\hline Gyraulus parvus (Say, 1817) & $\mathrm{xxx}$ & $\mathrm{xxx}$ & $\mathrm{xxx}$ & $\mathrm{xxx}$ & $\mathrm{xxx}$ & $\mathrm{xxx}$ & $\mathrm{xxx}$ & $\mathrm{xxx}$ & $\mathrm{xxx}$ & $\mathrm{x}$ & $\mathrm{xxx}$ & $\mathrm{xxx}$ & 12 \\
\hline Hippeutis complanatus (Linnaeus, 1758) & & & & & $\mathrm{x}$ & $\mathrm{x}$ & & & & & & & 2 \\
\hline Anodonta anatina (Linnaeus, 1758) & & & $\mathrm{x}$ & & & & & & & & & $\mathrm{x}$ & 2 \\
\hline Anodonta cygnea (Linnaeus, 1758) & & & & & & & $\mathrm{x}$ & & & & & & 1 \\
\hline Musculium lacustre (O. F. Müller, 1774) & & & & & & & & & & & & $\mathrm{x}$ & 1 \\
\hline Number of species & 7 & 6 & 9 & 5 & 9 & 9 & 6 & 9 & 7 & 5 & 8 & 9 & \\
\hline
\end{tabular}

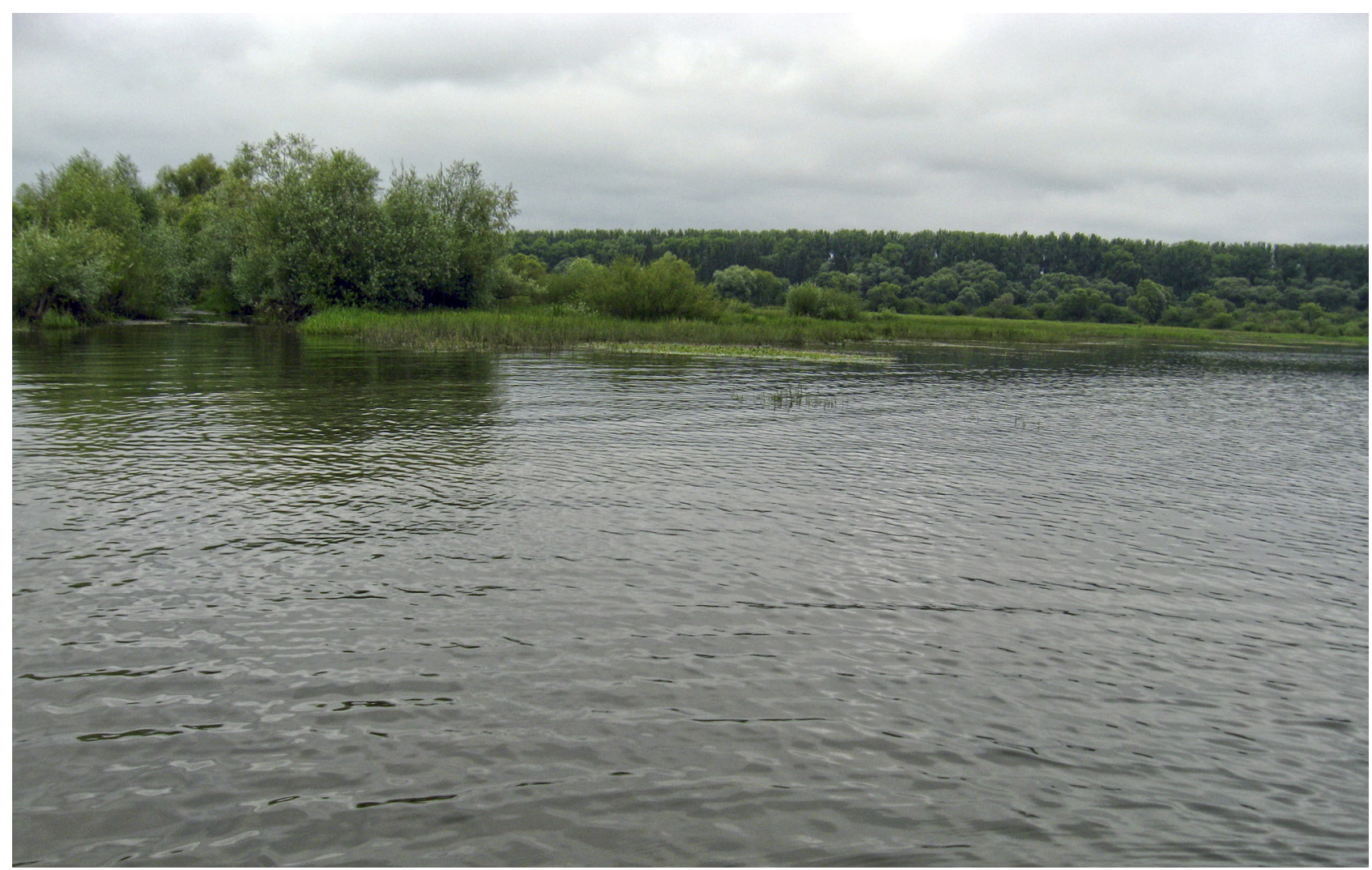

Fig. 2. Northern shore with the littoral zone overgrown by macrophytes and with extensive wetlands (site No. 8). Photo: LUBOŠ BERAN 
Table 2. List of aquatic molluscs recorded at different periods: 1982-1990 (LJUČIVJANSKÁ 1991, ŠTEFFEK 1991, ŠTEFFEK \& NAGEL 2004); 2020 - this study

\begin{tabular}{|c|c|c|}
\hline Species & $1982-1990$ & 2020 \\
\hline Viviparus acerosus (Bourguignat, 1862) & & $\mathrm{x}$ \\
\hline Potamopyrgus antipodarum (Gray, 1843) & & $\mathrm{x}$ \\
\hline Valvata cristata O. F. Müller, 1774 & $\mathrm{x}$ & \\
\hline Valvata piscinalis (O. F. Müller, 1774) & & $\mathrm{x}$ \\
\hline Galba truncatula (O. F. Müller, 1774) & $\mathrm{x}$ & $\mathrm{x}$ \\
\hline Stagnicola turricula (Held, 1836) & & $\mathrm{x}$ \\
\hline Radix auricularia (Linnaeus, 1758) & $\mathrm{x}$ & $\mathrm{x}$ \\
\hline Radix labiata (Rossmässler, 1835) & $\mathrm{x}$ & \\
\hline Radix lagotis (Schrank, 1803) & & $\mathrm{x}$ \\
\hline Aplexa hypnorum (Linnaeus, 1758) & & $\mathrm{x}$ \\
\hline Physa acuta (Draparnaud, 1805) & & $\mathrm{x}$ \\
\hline Anisus leucostoma (Millet, 1813) & $\mathrm{x}$ & \\
\hline Gyraulus albus (O. F. Müller, 1774) & $\mathrm{x}$ & $\mathrm{x}$ \\
\hline Gyraulus crista (Linnaeus, 1758) & $\mathrm{x}$ & $\mathrm{x}$ \\
\hline Gyraulus parvus (Say, 1817) & $\mathrm{x}$ & $\mathrm{x}$ \\
\hline Hippeutis complanatus (Linnaeus, 1758) & $\mathrm{x}$ & $\mathrm{x}$ \\
\hline Segmentina nitida (O. F. Müller, 1774) & $\mathrm{x}$ & \\
\hline Anodonta anatina (Linnaeus, 1758) & $\mathrm{x}$ & $\mathrm{x}$ \\
\hline Anodonta cygnea (Linnaeus, 1758) & & $\mathrm{x}$ \\
\hline Musculium lacustre (O. F. Müller, 1774) & $\mathrm{x}$ & $\mathrm{x}$ \\
\hline Pisidium amnicum (O. F. Müller, 1774) & $\mathrm{x}$ & \\
\hline Pisidium casertanum (Poli, 1791) & $\mathrm{x}$ & \\
\hline Pisidium henslowanum (Sheppard, 1823) & $\mathrm{x}$ & \\
\hline Pisidium obtusale (Lamarck, 1818) & $\mathrm{x}$ & \\
\hline Number of species & 16 & 16 \\
\hline
\end{tabular}

Valvata piscinalis, Radix auricularia and Gyraulus parvus were found in more than 10 sites each, Potamopyrgus antipodarum, Stagnicola turricula, Radix lagotis, Physa acuta and Gyraulus crista were recorded in 5-10 sites each, while the number of sites for the remaining species ranged from one to four.

Rich assemblages composed mainly of gastropods were found at sites with littoral zone overgrown by macrophytes (sites No. 3, 5-9, 11-12, Fig. 2) while sites with sparse macrophyte vegetation were inhabited by fewer species (e.g., sites No. 1-2, 4, 10, Fig. 3 ). The diversity and abundance of bivalves were very small. Only three species were found at one or two sites each and always as few specimens.

Due to the existence of historical data (LUČIVJANSKÁ 1991, ŠTEFFEK 1991, ŠTEFFEK \& NAGEL 2004), the present results could be compared with the earlier surveys (Table 2).

Abundant populations of Viviparus acerosus which is listed as Vulnerable in the Red List of molluscs of Slovakia (ŠTEFFEK \& VAVROVÁ 2006) were found at three sites and this record is outside its known range in Slovakia. R. lagotis was found in seven sites. It is the first reliable record of this species in Slovakia.

The native Aplexa hypnorum, Anodonta cygnea and the non-native Potamopyrgus antipodarum and Physa acuta were found in this area for the first time and their sites are outside the known range in Slovakia (HORSÁK et al. 2020).

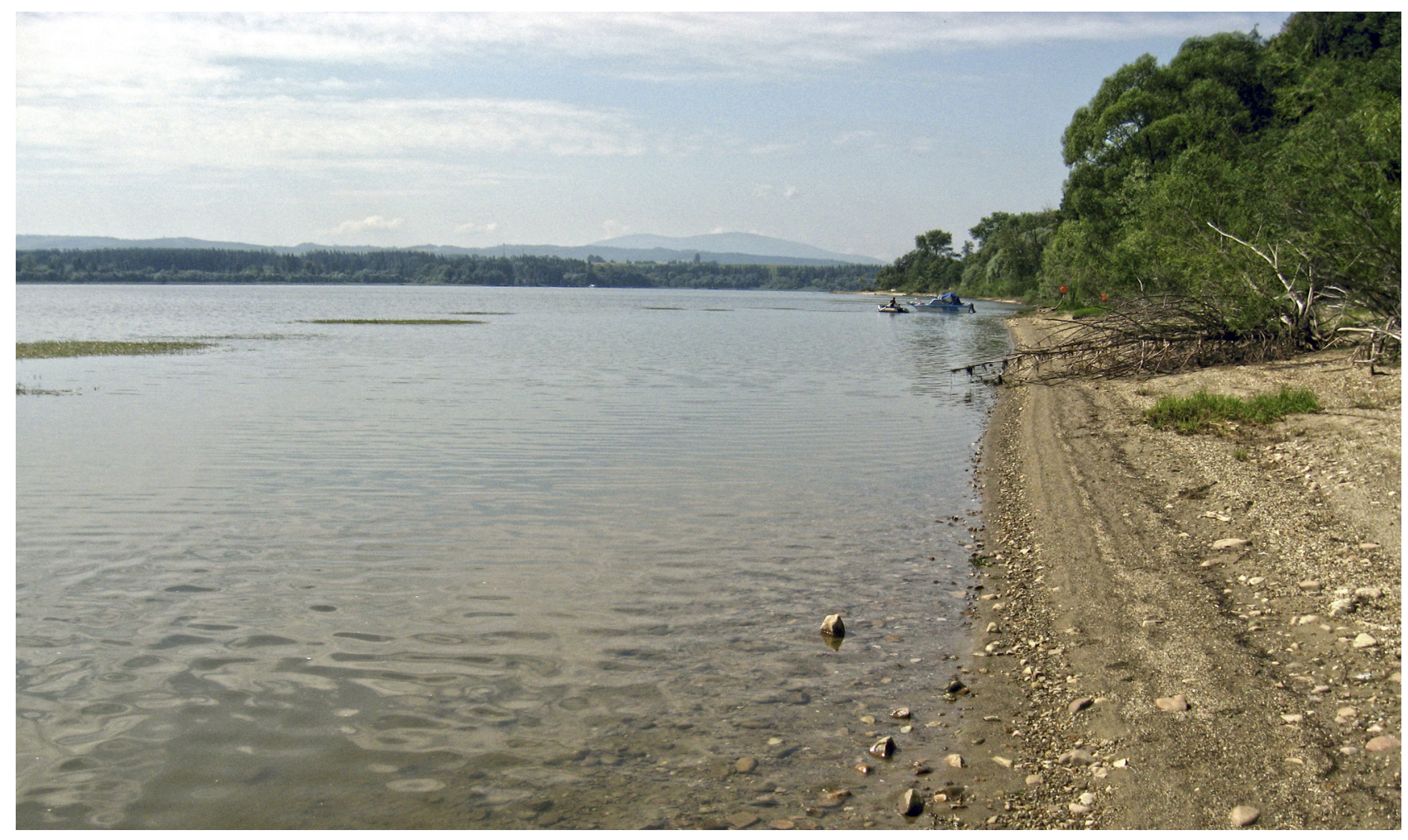

Fig. 3. Shore of the Orava dam reservoir nearly bare of vegetation (site No. 10). Photo: LUBOŠ BERAN 


\section{DISCUSSION}

The Orava dam reservoir provides appropriate habitats for abundant populations of species, which prefer standing waters; it differs from natural habitats of the area, such as nutrient-poor small rivers, brooks, springs, or small wetlands. Although it is situated at higher altitude, the reservoir is inhabited by richer mollusc assemblages and by many species, which are more common in lowlands. A similar situation is observed, for example, in the Lipno dam reservoir (48.7 $\mathrm{km}^{2}$ ) in the Czech Republic which is situated in the altitude of $725 \mathrm{~m}$ a.s.l. The Vltava River upstream of the reservoir is inhabited by poor assemblages, which are typical of nutrient-poor waters, while the reservoir harbours rich mollusc assemblages composed of 26 species; for many of them the Lipno reservoir is the highest-situated site of occurrence in the Czech Republic (BERAN \& DVOŘÁK 2006).

The small abundance and poor diversity of bivalves in the Orava reservoir are surprising. While abundant populations of six species ( 5 unionids) were found in 2020 in the second biggest dam reservoir in Slovakia, Zemplínská Šírava (BERAN 2020), 10 bivalves (4 unionids) in the Lipno dam reservoir in the Czech Republic (DVOŘÁK \& BERAN 2004, BERAN \& DVOŘÁK 2006), or 14 bivalves (4 unionids) in each of the two studied dam reservoirs in Poland: the Zegrzyński reservoir and the Sulejów reservoir (JURKIEWICZKARNKOWSKA 2004), only very scattered occurrences of three species ( 2 unionids) were found in the Orava reservoir. The Zemplínská Śírava reservoir and the two reservoirs in Poland are situated in the valleys of bigger rivers so the higher number of bivalves is understandable, but the Lipno reservoir lies at an even higher altitude than the Orava reservoir and yet its number of bivalves is significantly higher. It is possible that some smaller bivalves of the family Sphaeriidae may occur in tributaries of the Orava reservoir that have not been studied. This is suggested by their historical occurrence, when Pisidium amnicum, P. casertanum, P. henslowanum and P. obtusale were found during the previous surveys (ŠTEFFEK \& NAGEL 2004).

In total, LJUČIVJANSKÁ (1991), ŠTEFFEK (1991) and ŠTEFFEK \& NAGEL (2004) listed 16 species (Table 2 ). Only eight species (Table 2) were found during both the previous and the present surveys. Snails Valvata cristata, Radix labiata, Anisus leucostoma and Segmentina nitida, as well as bivalves Pisidium amnicum, $P$. casertanum, $P$. henslowanum and P. obtusale were found only during the previous research. $R$. labiata is common and widespread, preferring nutrient-poor habitats; its occurrence in the dam reservoir is probable, especially in its tributaries, as is the occurrence of the pea mussels $P$. amnicum and $P$. henslowanum. On the other hand, due to its shell variation, the species can be confused with the similar R. lagotis. V. cristata, A. leucostoma, S. nitida and P. obtusale inhabit wetlands and their occurrence is possible in the extensive wetlands along the northern shore of the reservoir. The methods used in the previous surveys differed from those used in this study and were largely limited to the analysis of sediments obtained near the dam during the discharge of the reservoir. It is impossible to locate precisely the places from which the shells were washed down. In some cases, the shells may have come from the upper reaches of the rivers outside the reservoir. Bythinella austriaca (von Frauenfeld, 1857) was also found in the sediments. This species occurs in springs and rivulets and its occurrence in the dam reservoir is almost excluded. For this reason, it was not included in the list of recorded species in Table 2.

On the other hand, V. acerosus, P. antipodarum, $V$. piscinalis, S. turricula, R. lagotis, A. hypnorum, P. acuta and $A$. cygnea were recorded only during the present survey. Some molluscs found in the reservoir in 2020 were observed in this area for the first time and their occurrence is noteworthy. R. lagotis was reliably recorded in Slovakia for the first time. This species is probably more common and widespread in Slovakia but due to the problematic identification it may have been overlooked or confused with other species of the genus Radix. $V$. acerosus is native to the Danube River basin and inhabits slow-flowing lowland rivers and canals. Its locality in the Orava reservoir is at least $150 \mathrm{~km}$ away from its known range mentioned in LISICKÝ (1991) and HORSÁK et al. (2020). Its unintentional introduction by humans, in connection with recreational activities, or by migratory birds, can be considered. The existence of dam reservoirs as sites, which attract recreational activities and/or are important for migratory birds may favour introduction of this species and also of other molluscs occurring in the reservoir. A similar phenomenon was observed in the case of the Švihov dam reservoir in the Czech Republic in the Elbe River basin, more than $100 \mathrm{~km}$ away from the native populations of $V$. acerosus in the Danube River basin in Southern Moravia (BERAN et al. 2019). This dam reservoir is a source of drinking water and entry is not allowed, so the introduction by migratory birds is more likely than by humans pursuing recreational activities. The occurrence of two non-native species ( $P$. antipodarum, $P$. acuta) outside their known range in Slovakia confirms their continuing spread.

\section{ACKNOWLEDGEMENTS}

I thank TOMÁš ČEJKA for providing publications with historical data, KATRIN SCHNIEBS for identification of $R$. lagotis and the anonymous reviewers for their valuable comments. 


\section{REFERENCES}

BERAN L. 2007. Vodní měkkýši přehradní nádrže Slapy (Česká republika). Malacologica Bohemoslovaca 6: 1116. Available online at http://mollusca.sav.sk (accessed 15 March 2007).

BERAN L. 2020. Aquatic molluscs of the Zemplínská Šírava dam reservoir (East Slovakia). Folia Malacologica 28: 114-120. https://doi.org/doi: 10.12657/folmal.028.006

BERAN L., DVOŘÁK L. 2006. New records of aquatic molluscs in the Lipno Reservoir and its surroundings. Silva Gabreta, Vimperk 12: 133-142.

BerAn L., HorsáK M., Hofman S. 2019. First records of Viviparus acerosus Bourguignat, 1862 (Gastropoda: Viviparidae) from the Czech Republic outside its native range. Folia Malacologica 27: 223-229. https://doi.org/10.12657/folmal.027.021

DVOŘÁK L., BERAN L. 2004. Remarkable records of aquatic molluscs in the Lipno Reservoir and its environs. Silva Gabreta 10: 97-106.

HORSÁK M., ČEJKA T., JUŘIČKOVÁ L., BERAN L., HORÁČKOVÁ J., HLAVÁČ J. Č., DVOŘÁK L., HÁJEK O., DivíšEK J., MAŇAS M., LOŽEK V. 2020. Check-list and distribution maps of the molluscs of the Czech and Slovak Republics. Available online at http://mollusca.sav.sk/ malacology/checklist.htm, checklist updated at January 12, 2021, maps updated on January 24, 2021.

JURKIEWICZ-KARNKOWSKA E. 2004. Malacocoenoses of large lowland dam reservoirs of the Vistula River basin and selected aspects of their function. Folia Malacologica 12: 1-56.

https://doi.org/10.12657/folmal.012.001

LISICKÝ M. J. 1991. Mollusca Slovenska. Veda, Bratislava.

LUČIVJANSKÁ V. 1991. Vyhodnotenie malakofauny z náplavu hornej Oravy. Význam náplavu pre zoológiu a ochranársku prax. Prehlad odborných výsledkov XXVII. TOP - Oravská priehrada: 27-32.

PetTS G. E., GuRnell A. M. 2005. Dams and geomorphology: research progress and future directions. Geomorphology 71: 27-47.

https://doi.org/10.1016/j.geomorph.2004.02.015

ŠTEFFEK J. 1991. Rozbor malakofauny z náplavu Oravskej priehrady po jej vypustení. Prehlad odborných výsledkov XXVII. TOP - Oravská priehrada: 17-22.

ŠTeFfeK J., NAGEL K. O. 2004. Vodné mäkkýše regiónu Orava. Zborník Oravského múzea (Dolný Kubín) 21: 185-193.

ŠTEFFEK J., VAVROVÁ L. 2006. Current ecosozological status of molluscs (Mollusca) of Slovakia in accordance with categories and criterion of IUCN - version 3.1. (2001). In: KYRYCHUK G. Y. (ed.). Molluscs: Perspective of Development and Investigation, 27-29th September 2006, Zhytomyr, Ukraine, pp. 266-276.

Received: March 3rd, 2021

Revised: April 9th, 2021

Accepted: April 11th, 2021

Published on-line: May 25th, 2021

\section{APPENDIX 1}

\section{LIST OF INVESTIGATED SITES}

The data in the list are as follows: site number, geographical co-ordinates, name of the nearest settlement, description of the site, date of investigation. For location of sites see Fig. 1

1 - 49²4'23.1"N, 19³1'08.3"E, Námestovo, E. shore of Slavický ostrov island, 3.8.2020;

2 - 49 $24^{\prime} 25.6^{\prime \prime} \mathrm{N}, 1^{\circ} 30^{\prime} 53.2^{\prime \prime} \mathrm{E}$, Námestovo, W. shore of Slavický ostrov island, 3.8.2020;

3 - 49 $24^{\prime} 01.4^{\prime \prime} \mathrm{N}, 1^{\circ} 30^{\prime} 53.5^{\prime \prime} \mathrm{E}$, Námestovo, S. shore of Orava dam reservoir at ferry, 3.8.2020;

$4-49^{\circ} 23^{\prime} 51.8^{\prime \prime} \mathrm{N}, 1^{\circ} 29^{\prime} 06.8^{\prime \prime} \mathrm{E}$, Námestovo, W. cove of Orava dam reservoir at bridge, 3.8.2020;

5 - 49 $23^{\prime} 48.7^{\prime \prime} \mathrm{N}, 1^{\circ} 28^{\prime} 50.3^{\prime \prime} \mathrm{E}$, Námestovo, W. cove of Orava dam reservoir, 3.8.2020;

6 - 49 $24^{\prime} 18.2^{\prime \prime} \mathrm{N}, 19^{\circ} 29^{\prime} 10.3^{\prime \prime} \mathrm{E}$, Námestovo, shore of Orava dam reservoir in Námestovo at skatepark, 5.8.2020;

$7-49^{\circ} 24^{\prime} 38.3^{\prime \prime} \mathrm{N}, 19^{\circ} 30^{\prime} 18.6^{\prime \prime} \mathrm{E}$, Námestovo, shore of Orava dam reservoir at Studnička hotel, 3.8.2020;

$8-49^{\circ} 25^{\prime} 16.9^{\prime \prime} \mathrm{N}, 19^{\circ} 30^{\prime} 51^{\prime \prime E}$, Zubrohlava, N. cove of Orava dam reservoir S of Zubrohlava, 5.8.2020;

9 - 49 $25^{\prime} 13.4^{\prime \prime} \mathrm{N}, 19^{\circ} 31^{\prime} 57.2^{\prime \prime E}$, Bobrov, N. cove of Orava dam reservoir SW of Bobrov, 5.8.2020;

10 - 49²4'29.7"N, 19³5'39.2"E, Trstená, E. shore of Orava dam reservoir, 5.8.2020;

$11-49^{\circ} 23^{\prime} 11.4^{\prime \prime} \mathrm{N}, 1^{\circ} 35^{\prime} 54.6^{\prime \prime} \mathrm{E}$, Trstená, E. cove of Orava dam reservoir, 5.8.2020;

$12-49^{\circ} 23^{\prime} 00.5^{\prime \prime} \mathrm{N}, 1^{\circ} 34^{\prime} 53.2^{\prime \prime E}$, Trstená, S. shore of Orava dam reservoir in Ústie nad Priehradou, 5.8.2020. 